\title{
Is E-Marketing the Future of Marketing Field
}

\author{
Paulus H. A. Andreki, Rashad Yazdanifard \\ Centre of Post Graduates Studies, Limkokwing University of Creative Technology, Cyberjaya, Malaysia \\ Email: paandreki@gmail.com, rashadyazdanifard@yahoo.com
}

Received 19 April 2014; revised 26 May 2014; accepted 2 July 2014

Copyright @ 2014 by authors and Scientific Research Publishing Inc.

This work is licensed under the Creative Commons Attribution International License (CC BY).

http://creativecommons.org/licenses/by/4.0/

(c) (i) Open Access

\begin{abstract}
Globalisation and technological improvements are imminent and those that embrace it today will be better prepared for tomorrow. E-marketing is growing at a dramatic pace and is impacting customer and market behaviours. This has forced firms to start incorporating e-marketing as the main form of marketing and try to meet their targeted customers' needs to the satisfaction. This paper investigates and states what is e-marketing, what the current trend of the marketing field is and what the future of the marketing field is. The paper has found and concluded that e-marketing is the future as it has been positively affected by the current technological change which has made the use of smart phones and gadgets a necessity.
\end{abstract}

\section{Keywords}

E-Marketing, Marketing Field, Future of Marketing

\section{Introduction}

Marketing in broad definition is all about identifying and meeting human and social needs. In a short definition, marketing is "meeting needs profitably". Marketing has pretty much been around forever in one form or another. Since the day when humans first started trading whatever it was, marketing has been there. This article explores the Internet as a marketing dissemination channel. Some practitioners and academics have dismissed the Internet and the current level of business interest in the Internet as hype, arguing that the Internet does not offer any new business models, or new opportunities for creating customer value. This position denies the central significance of relationships in business activity.

Marketing was the stories they used to convince other humans to trade. Humans have come a long way since then, (Well, we like to think we have) and marketing has too [8]. The methods of marketing have changed and improved, and we've become a lot more efficient at telling our stories and getting our marketing messages out there. E-Marketing is the product of the meeting between modern communication technologies and the age-old marketing principles that humans have always applied. 
The Internet, web and related information technologies have proven to be transformational. While these technologies have impacted all parts of the corporation, the marketing function has perhaps been most affected. E-marketing has emerged as a significant part of every global corporation's marketing side. As international acceptance of the Internet and web increases, the scope of international e-marketing now is transited from possibility to reality, and without it, incorporating it will come into failure.

E-marketing strategies entail utilizing existing and emerging communication and data networks to impart personalized and uninterrupted communication between the firm and its customers and to provide value above traditional networks [1]. Electronic business (e-business) solutions are currently evolving on a global scale and all businesses will like to increase to their market share and widen their client base, so they are more engaged. IBM regards e-business as: “...the use of Internet technologies to improve and transform key business process [2].

Relationships are important at both individual and organisational level (the Firm doing the Marketing and the Consumers that the information is meant for). Relationships within the value chain both within organisations and between organisations are crucial to the creation of competitive advantage and the generation of unique propositions regarding customer value [3]. Relationships with consumers, as stated by Buttle [3], are recognised to be at the heart of customer attraction and retention. The establishment and maintenance of such relationships is achieved through the practical science and conceptual frameworks of e-Marketing. However, in order to understand the opportunities and issues faced by e-marketing, if e-marketing is indeed the future of the marketing field, we should examine what marketing, e-marketing and the current trend in marketing is and what the future holds.

\section{Research Methodology}

This study philosophically falls under interpretivism class, undertaken research approach is explanatory and research strategy is literature survey. Consequently this study used secondary data and qualitative analysis techniques. International journals as well as proceedings are dug up through international well-recognized databases like Emerald, Google scholar and Ebsco. Journals were collected over a week-period and reviewed by the author over the subsequent period of time. The Journal emphasized on Journals that were written after 2007 onwards, but was not limited to that time frame as it has used others also before that year (2007). Discussions around the design and the objective of the study were done, with the Lecturer and some students in the Postgraduate Centre, mostly MBAs students in order to improve the flow of study. The arrangement of literature survey and review was planned to be started with reviewing the concept of conventional marketing mix and Internet marketing and then scrutinizing and elaborating the concepts of Internet marketing mix to be further used by e-marketers, researchers and other practitioners involved in online marketing and customer-oriented decision making.

\section{The Marketing Field}

The paper looks at the marketing field, putting in context where has the field evolved from, where it is now and where it is heading. Formally or informally, people and organizations engage in vast number of activities we could call marketing. Good marketing has become increasingly vital for success [4]. But what constitutes good marketing is constantly evolving and changing. Good Marketing is no accident, but a result of careful planning and execution using tools and techniques [4]. Definitions of marketing count for little if businesses do not develop a process, culture and set of operational procedures to actually “do" marketing [5]. Marketing is marketing, irrespective of the product or marketplace.

The current marketing field has evolved and includes from basic marketing analyses, via target market strategy decisions, to the determination of tactical marketing mix programmes and controls, there are marked differences in the issues encountered and the approaches deployed between consumer and industrial marketing.

The marketing field puts the following in context:

Understanding Competitors: Perhaps because of the prominence of brands and the high profile in-home media adopted in much consumer promotion, most consumer marketers are aware of their rivals' brands and marketing tactics. All too often, such competitive understanding is only superficial, but consumer marketers at least exhibit strong awareness of their like for-like competitive arena [1].

Market Segmentation: Perhaps one of the most important aspects of marketing [1], market segmentation, is frequently deployed by practitioners in all markets. 
Branding: Branding exists primarily for identification and to smooth the task of differentiating products [1]. There is a strong psychological ingredient inherent in consumer branding with many consumers, notably of supermarket merchandise, exhibiting strong loyalty to their favoured brands.

The Marketing mix: McCarthy's "4Ps" have re-appeared in many marketing texts for around three decades. Product, promotion, pricing and place (channels) are still considered to be the tactical marketing toolkit manipulated by most marketing practitioners [1]. The Modern Marketing has changed and renamed the "4Ps". As highlighted by Kotler and Keller [4], the Modern Ps are: People reflects, in part, internal marketing and the fact that employees are critical to marketing success. Marketing will only be as good as the people inside the organization. Processes reflect all the creativity, discipline, and structure brought to marketing. In other words, marketers must and should avoid ad hoc planning and decision making. Programs reflect all the firm's consumerdirected activities.

\section{E-Marketing}

E-marketing is growing at a dramatic pace and is significantly impacting customer and business market behaviours. As a result, most firms started developing e-marketing strategies. E-marketing strategies entail utilizing existing and emerging communication and data networks to impart personalized and uninterrupted communication between the firm and its customers and to provide value above traditional networks [1]. Marketing also became more organization initiated as products were first manufactured and then marketed [6]. E-marketing creates a fundamental shift in business and consumer behaviours similar to that associated with the introduction of smart phones that reduced the need for channel immediacy. E-marketing uses the Internet as a platform that allows firms to adapt to the needs of customers, reduces transaction costs, and allows customers to move from time and location-based behaviours toward non-temporal and non-locational behaviours [1]. E-marketing is similar to agricultural-age marketing, with direct recurring relationships between consumer and producer but with lower costs [6]. The main advantages of e-marketing are cost reduction and enhancing reach. The cost of an e-marketing platform is typically lower than other marketing platforms such as face-to-face salespeople or middlemen/distributors [1]. It allows firms to cut on sales agent, and thus just focus on creating a database that can reach all their clients and potential clients. In addition, e-marketing allows firms to reach customers that may not be accessible due to temporal and locational limitations of existing distribution channels. E-marketing platforms increase reach and reduce costs by providing three areas of advantage for customers. First, the marketing firm can provide unlimited information to customers without human intervention. Second, the e-marketing firm can create interactions by customizing information for individual customers that allow customers to design products and services that meet their specific requirements [1]. Finally, e-marketing platforms can allow transactions between customers and firms that would typically require human contact as in the case of successful firms such as Dell and amazon.com.

\section{The Future of Marketing}

The future is important, yet it is notoriously difficult to predict, and the difficulty increases as the time horizon extends. But Globalisation of the Markets; Increased importance of Information Technology; and new forms of competition are one of the things that will be high on the influence of the future of marketing, stated by Baker [7]. Globalization and technological advances have greatly advanced the business opportunities for Marketing. The increased number of people travelling worldwide in addition to international migration has meant that marketing innovations has to meet the needs of the clients and have to be convenient for everyone. The marketing function of the future will continue to be polarized. Aker [4] highlighted that in a growing number of businesses, marketing will have more of a strategic role. That means the marketing group must have the skills and talent to think strategically and the credibility to influence the process to think in terms of building branded assets rather than immediate sales [4]. Marketing leaders embarking on a capability journey must embrace collaboration with counterparts across the organisation, HR and Learning and Development colleagues, to add expertise to the people and skills agenda. They need to work sales, product, and finance colleagues to support process improvements and to implement the necessary e-marketing measures. Marketing is changing, and we should expect it to change. Accounting has been with us since the late 1400's [4], and is likely to be with us for some time yet. This is not to say that it has evolved and changed during that time, but the essential feature-to provide a fair and accurate statement of the financial health of a firm-has remained unaltered. With Marketing, we do expect it to 
evolve from door-to-door guerrilla marketing to a more diversified e-marketing, smart phones have become a necessity, technology has increased and marketer need to find a way for the future and see to it that e-marketing becomes their primary target.

\section{Discussion}

The paper outlined what is marketing in general, by defined and explaining the narrow and broad definition. E-marketing is the future as the paper has highlighted. New forms of marketing can then be incorporated in the form of new social media, print media and be linked to potential consumers and clients via their smart phones. Recent reports have shown that there are more than one billion smart phones in the world [8]. The people of today have become more attached to their gadgets more than anything in this world, they watch their favourite movies there, read their mails, news, play music and everything (even their daily dairy/daily planner has been incorporated to their gadgets). So Marketer should put this in context and realise that the only way to get the consumers attention is through e-marketing. The paper has also pointed out that e-marketing has some challenges but the most important aspect is change is essential and those that do not accept it will be left behind.

\section{Conclusion}

This author has concluded that "e-marketing is the future of the marketing field". With common objectives, right method, any one that does incorporate e-marketing will be left with small percentage of people to market to, in the sense that the majority have moved on with technology and are using gadgets and smart phones. However, the view presented here is that the future belongs to e-marketing in the marketing field, but not limited to it. What do you think?

\section{Acknowledgements}

I am particularly grateful to the Lord Almighty for giving me strength and wisdom to be where I am. Without him, I am nothing.

Secondly, I would like to express my very great appreciation to Dr. Rashad Yazdanifard for his valuable and constructive suggestions during the planning, development and finalisation of this paper. His willingness to give his time so generously has been very much appreciated. I would also like to extend my thanks to the MBA's students at the Limkokwing University of Creative Technology, for their information sharing and suggestion during the paper writing.

\section{References}

[1] Watson, R.P., Leyland, F.P., Berthon, P. and Zinkham, G. (2002) U-Commerce: Expanding the Universe of Marketing. Journal of the Academy of Marketing Science, 30, 333-347. http://dx.doi.org/10.1177/009207002236909

[2] Olhager, J. and Rudberg, M. (2002) Manufacturing Strategy and E-Business: An Exploratory Study. Integrated Manufacturing Systems, 14, 334-345. http://dx.doi.org/10.1108/09576060310469716

[3] Rowley, J. (2004) Just Another Channel? Marketing Communications in E-Business. Marketing Intelligence \& Planning, 22, 24-41. http://dx.doi.org/10.1108/02634500410516896

[4] Kotler, P. and Keller, K.L. (2012) Marketing Management. Pearson Education Limited, London.

[5] Harker, J.M. (1999) Relationship Marketing Defined? An Examination of Current Relationship Marketing Definitions. Marketing Intelligence \& Planning, 17, 13-20. http://dx.doi.org/10.1108/02634509910253768

[6] Sheth, N.J. and Sharma, A. (2005) International E-Marketing: Opportunities and Issues. International Marketing Review, 22, 611-622. http://dx.doi.org/10.1108/02651330510630249

[7] Baker, M. (1998) Marketing in the Future. Australasian Marketing Journal, 6, 7-13.

[8] O’Shaughnessy, N. (2001) The Marketing of Political Marketing. European Journal of Marketing, 35, $1047-1057$. http://dx.doi.org/10.1108/03090560110401956 
Scientific Research Publishing (SCIRP) is one of the largest Open Access journal publishers. It is currently publishing more than 200 open access, online, peer-reviewed journals covering a wide range of academic disciplines. SCIRP serves the worldwide academic communities and contributes to the progress and application of science with its publication.

Other selected journals from SCIRP are listed as below. Submit your manuscript to us via either submit@scirp.org or Online Submission Portal.
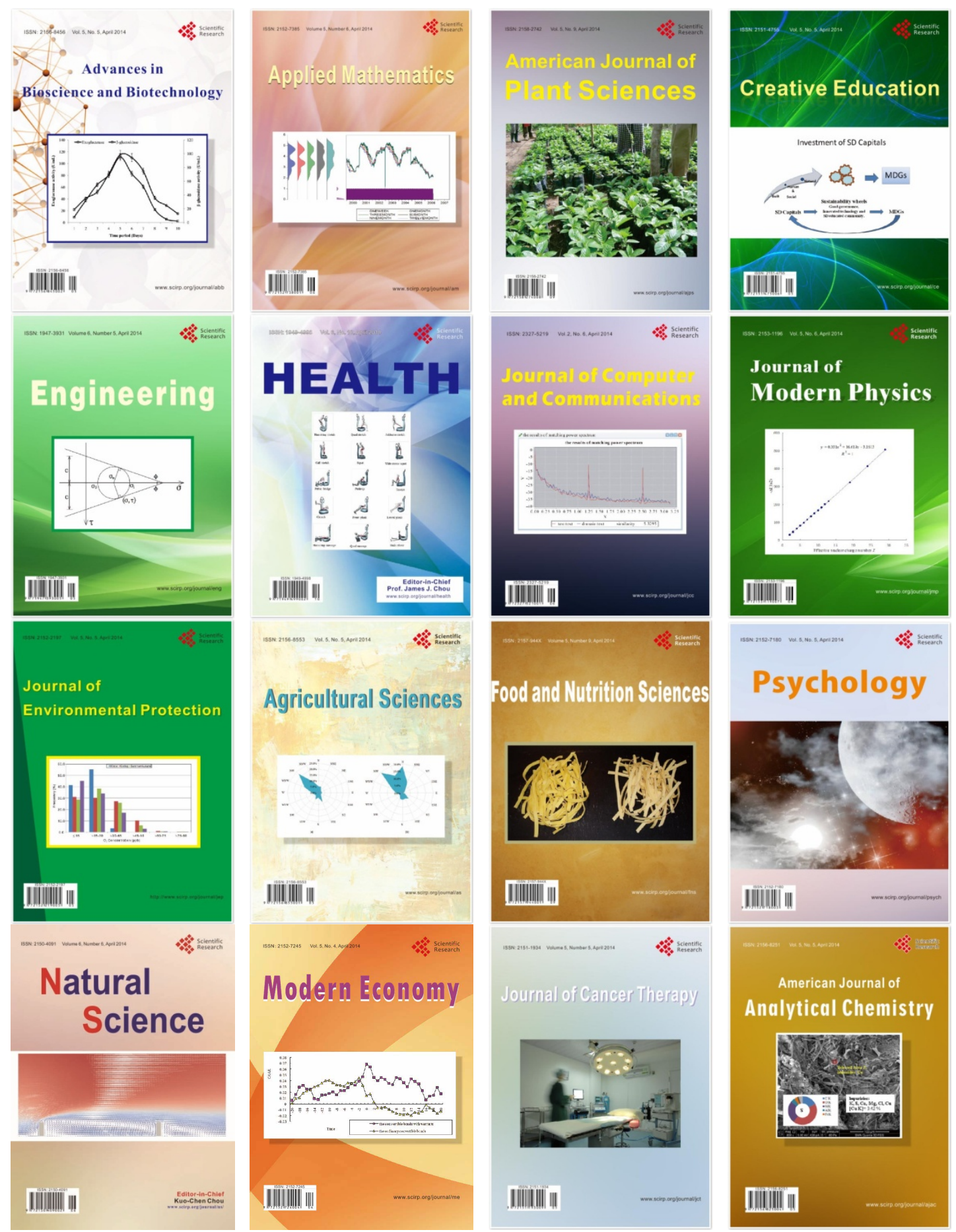